\title{
The efficacy of Echinacea (Echinacea purpurea) methanol extract on growth performance in grey mullet (Mugil cephalus)
}

P Akbary ${ }^{1 *}$, S Kakoolaki ${ }^{2}$, H. Salehi ${ }^{2}$, M J Zorriehzahra ${ }^{2}$, A Sepahdari ${ }^{2}$, M R Mehrabi ${ }^{2}$ and S Jadgal $^{3}$

${ }^{1}$ Department of Marine Sciences, Chabahar Maritime University, Fisheries group, Chabahar, Iran

${ }^{2}$ Iranian Fisheries Science Research Institute (IFSRI), Agricultural Research Education and Extension Organization (AREEO), Tehran, Iran

${ }^{3}$ Offshore Research Center, Iranian Fisheries Science Research Institute (IFSRI), Agricultural Research Education and Extension Organization (AREEO), Chabahar, Iran

Received:April 2016

\begin{abstract}
This experiment was conducted to evaluate the efficacy of different levels of Echinacea (Echinacea purpurea) methanol extract on the growth performances (final weight (FW), daily growth ratio (DGR), feed conversion rate (FCR), voluntary feed intake (VFI) and protein efficiency ratio (PER) and some of hematological parameters (hemoglobin $(\mathrm{Hb})$, hematocrit (Hct), red blood cell (RBC) and white blood cell (WBC) of grey mullet (Mugil cephalus). The experiment was conducted in a completely randomized design with 360 of larvae (with average weight of $0.75 \pm 0.03 \mathrm{~g}$ ) in 4 treatments: control group
\end{abstract}

Correspondence P Akbari, Department of Marine Sciences, Chabahar Maritime University, Fisheries group, Chabahar, Iran (email: paria.akbary@gmail.com)
Accepted: September 2016

without using Echinacea extract, an another groups (treatment 2, 3 and 4) the amounts of this extract were 50,100 and $200 \mathrm{~g} / \mathrm{kg}$ food.

The highest FW $(4.22 \pm 0.11 \mathrm{~g})$, DGI $(1.72 \pm 0.50 \%)$ and the lowest FCR $(0.95 \pm 0.05)$ and VFI $(1.77 \pm 0.05 \%)$, were observed in treatment 4 . But treatment 4 in all of these growth parameters did not show a significant difference compared with treatment 3 ( $\mathrm{P}>$ 0.05). After 60 days, treatments 3 and 4, showed significantly higher $\mathrm{RBC}, \mathrm{WBC}, \mathrm{Hb}$ and Hct than those fed the control diet. Finally, the present results suggest that diet containing 100 and $200 \mathrm{~g} \mathrm{~kg}^{-1}$ extract could improve growth and hematological parameter of $M$. cephalus.

Keywords: Mugil cephalus, Echinacea purpurea, Methanol extract, Growth yield, Hematological parameter. 


\section{Introduction}

Hormones, antibiotics, vitamins and several other chemicals have been tested as growth promoters, antibacterial and other purposes in mariculture (Jayaprakas \& Sambhu 1996 ).

Even though the above chemicals have positive effects on the fishes and shrimps they cannot be recommended in commercial mariculture operations due to their residual effects in the muscle of fishes and prawns (Sahu, Das, Mishra, Pradhan \& Sarangi 2007). In marine fish hatcheries, the indiscriminate use of antibiotics in prophylactic treatment has led to the development of the resistant strains and the need to switch over to other antibiotics (Nwabueze 2012). The antibiotics also may reduce the larval growth and inhibit defense mechanisms of the fish larvae. Many of the antibiotics and other synthetic drugs have shown sensitization reaction and other undesirable side effects (Shalaby, Khattab \& Abdel Rahman 2006).

Plants are natural sources of safer and cheaper chemicals. Plant products have been reported to promote various activities like antistress, growth promotion, appetite stimulation and immunostimulation in aquaculture practices (Citarasu, Sekar, Babu \& Marian 2002, Sivaram, Babu, Citarasu, Immanuel, Murugadass \& Marian 2004 ).

Echinacea (Echinacea purpurea) also known as the purple coneflower, is an herbal medicine with positive effects on various immune parameters (Guz, Sopinska \& Oniszczuk 2011 , Medina-Beltrán, LunaGonzález, Fierro-Coronado, Campa-Córdova ,
Peraza-Gómez, Carmen Flores-Miranda \& Gutiérrez Rivera 2012). It is usually used in supportive therapy of colds and chronic infections of the respiratory and the lower urinary tract. Although many of the active compounds of E. purpurea have been identified, the mechanism of its action remained unknown (Aly, John, El-Naggar \& Mohamed 2007 ). Echinacea includes a diversity of medically essential materials that perform a role in its therapeutic effects. They involve alkylamides, caffeic acid derivatives, glycoproteins, polysaccharides, polyacetylenes, phenolic mixtures, cinnamic acids, essential oils and flavonoids (Aly et al. 2007 ). Echinacea inclusion in fish feeds has been reported to increase growth performance in rainbow trout (Oncorhynchus mykiss) (Oskoii, Kohyani, Parseh, Salati \& Sadeghi 2012), Nile tilapia (Oreochromis niloticus) (Aly et al. 2007 , Maass, Bauer, Paulicks, Bohmer \& Roth-Maier 2005 ), angelfish (Pterophyllum scalare) (Kasiri, Farahi \& Sudagar 2011) and in guppy (Poecilia reticulate) (Guz et al. 2011 ). Przybilla \& Wei (1998) mentioned that $E$. purpurea contains main ingredients which promote the performance of the intestinal flora, thereby improving digestion and enhancing the utilization of energy, leading to improved growth. Also, hematological parameters of rainbow trout (Oskoii et al. 2012) and Nile tilapia has been improved by the inclusion of Echinacea in fish feed.

The grey mullet (Mugil cephalus) belonging to Mugilidae, due to its adaptability to captivity 
conditions and high commercial value is cultured in Mediterranean region (Turan, Gürlek, Ergüden, Yağlioğlu \& Öztürka 2011 ). To our knowledge, this is the first study focused on the role of Echinacea (Echinacea purpurea) methanol extract on the growth yield and hematological parameter of grey mullet.

Our study was aimed to investigate efficacy of different levels of E. purpurea methanol extract on the growth performances, final weight $(\mathrm{FW})$, daily growth ratio (DGR), feed conversion rate (FCR), voluntary feed intake (VFI) and protein efficiency ratio (PER) and some of hematological parameters hemoglobin $(\mathrm{Hb})$, hematocrit (Hct), red blood cell (RBC) and white blood cell (WBC) of $M$. cephalus.

\section{Materials and Methods}

\section{Fish}

A total number of 360 grey mullets (mean initial weight of $8.32 \pm 0.39 \mathrm{~g}$ ) (mean $\pm \mathrm{SD}$ ) at Mid April 2015, were captured from the coastal water of Chabahar for quarantine and health check purposes. Fish were acclimatized for one week in 400-L tank and then were fed with commercial diet. Water was exchanged $(50 \%)$ in daily manner and throughout experiment water quality was monitored weekly. Salinity, temperature, dissolved oxygen concentration; ammonia nitrogen concentration and $\mathrm{pH}$ were measured about $38 \mathrm{~g} \mathrm{~L}^{-1} 28.2^{\circ} \mathrm{C} \pm 0.57 .01 \pm 0.87 \mathrm{mg} \mathrm{L}^{-1}, 0.11 \pm$ $0.04 \mathrm{mg} \mathrm{L}^{-1}$ and $7.8 \pm 0.4$ respectively. ad labium with commercially available pelleted feeds were fed to Fish (Beyza Feed Mill
Company, Iran) at the rate $3 \%$ of body weight followed by biomass assessment by bulk weighting every 7 days $(n=30$ for each group).The daily ration was subdivided into two parts and fed at 9:00 hours and 16:00 hours for 8 weeks to fish.

\section{Preparation of Echinacea methanol extract}

Two kg of E. purpurea plant were obtained from the local market in Shiraz. It was oven dried at $60^{\circ} \mathrm{C}$, powdered by mortar and pestle and sieved, then $50 \mathrm{~g}$ Echinacea powder was left during $48 \mathrm{~h}$ in $99 \%$ methanol $10 \mathrm{~L}$ $(10 \% \mathrm{w} / \mathrm{v})$ in room temperature $\left(24 \pm 1.2^{\circ} \mathrm{C}\right)$ and the resulting extract was concentrated to 300 $\mathrm{ml}$ using rotary evaporator (IKA, Germany) giving the extract of $6.1 \mathrm{~g}$ of Echinacea powder $\mathrm{ml}^{-1}$. This extract was sprayed on the diet after dilution in $300 \mathrm{ml}$ of distilled water (Choi, Lee \& Nam 2015).

\section{Diet preparation}

A commercial extruded pellet of $1.6 \mathrm{~mm}$ size (Beyza Feed Mill, Iran) was employed as the experiment diet. The analyzed composition was as follows moisture $10 \%$, fiber $1.7 \%$, crude protein $50 \%$, and crude fat $13.5 \%$ and crude ash $14.8 \%$. Four diets were prepared to contain $0 \%$ Echinacea extract (control diet), 50, 100 and $200 \mathrm{~g} / \mathrm{kg}$ Echinacea extract. In order to volatilize remaining methanol, the mixture of Echinacea extracts and distilled water $(40 \mathrm{~mL})$ was sprayed on the experiment diets. It was finally dried at room temperature at $30^{\circ} \mathrm{C}$ for $48 \mathrm{~h}$. All diets were stored at $-20^{\circ} \mathrm{C}$ until used (Choi et al. 2015).

\section{Experimental design and feeding diet}


The study was conducted over a period of 60 days to evaluate the efficiency of Echinacea extract in promoting growth and hematological parameter of grey mullet. Grey mullet larvae $(n=360)$ were divided into four equal groups. Three replicates were used in each group and randomly assigned to 12 plastic tanks each, 60L. Control group (1) was fed with basal diet and the remaining groups (2-4) were fed with 50,100 and $200 \mathrm{~g}$ concentrations of Echinacea extract/kg diets respectively.

\section{Sample collection and analysis}

At the end of experiment, all fish were individually weighted to ensure a homogenous sampling. Clove powder $\left(5 \mathrm{mg} \mathrm{L}^{-1}\right)$ was used to anesthetize fish ( $n=60$ for each treatment). The specimens were individually weighted to estimate final weight (FW), daily growth ratio (DGR), feed conversion rate (FCR), voluntary feed intake (VFI) and protein efficiency ratio (PER) Also, number of nine fish from each treatment were anesthetized and blood samples were taken after excising caudal peduncle and were transferred to heparinized sterile tubes 1-1.5 mL for the hematological tests (Shaluei, Hedayati, Jahanbakhshi \& Baghfalaki 2012). Numbers of white blood cell and red blood cell tests were determined soon on fresh blood. Hematocrit values ( $\mathrm{Ht} \%$ ) were soon measured after sampling through putting fresh blood in glass capillary tubes and were centrifuged for $5 \mathrm{~min}$ at $10,000 \mathrm{rpm}$ in a microhematocrit centrifuge (Hettich, Germany) and then packed cell volume was measured (Goldenfarb, Bowyer, Hall \& Brosious 1971). Hb as described by Lee, Foerster, Jukens, Paraskevas, Greer \& Rodgers (1998).

\section{Statistical analysis}

All measurements were repeated twice. Data were evaluated using one- way analysis of variance (ANOVA).Groups were considered to be significantly different if $P<0.05$. When a significant $F$ value was obtained for ANOVA the differences between all groups were tested by using Duncan multiple comparisons test. Normality was tested using the KolmogorovSmirnov test. Leven's test was carried out to verify the homogeneity of variance. Non homogenous data were arcsine transformed before further statistical analysis. All statistics were performed using SPSS for windows versions 16. Data are reported as means \pm standard Error.

\section{Results}

The result of different concentrations of extract on final weight $(\mathrm{FW})$, daily growth ratio (DGR), feed conversion rate (FCR), voluntary feed intake (VFI) and protein efficiency ratio (PER) of M. cephalus is shown in Table 1. These results indicated that FW, DGR and PER in treatments 3 and 4 were significantly $(\mathrm{P}<0.05)$ higher than treatments 1 and 2 after 60 days of culture. No significant difference was shown in FW, VFI, FCR, DGR and PER between treatments 1 and 2. The lowest FCR $(0.95 \pm 0.05)$ was found in treatment 4 fish. There was significant difference in FCR between grey mullet fed with diet containing $200 \mathrm{~g}$ Echinacea extract $\mathrm{kg}^{-1}$ and control treatment $(\mathrm{P}<0.05)$. The lowest VFI was observed in treatments 3 and 4. No significant difference was shown in VFI 
either treatments 1 and 2 or treatments 3 and 4

$(\mathrm{P}>0.05)$.

Table 1 Initial weight (IW) final weight (FW), daily growth ratio (DGR), feed conversion rate (FCR), voluntary feed intake (VFI) and protein efficiency ratio (PER) of Mugil cephalus fed diets with or without Echinacea extract for 60 days.

\begin{tabular}{ccccccc}
\hline Treatment & IW $(\mathrm{g})$ & FW $(\mathrm{g})$ & DGR $(\%)^{\mathrm{a}}$ & VFI $(\%)^{\mathrm{b}}$ & FCR $^{\mathrm{c}}$ & PER $^{\mathrm{d}}$ \\
\hline 1 & $0.75 \pm 0.06^{\mathrm{a}}$ & $1.63 \pm 0.08^{\mathrm{a}}$ & $0.80 \pm 0.05^{\mathrm{a}}$ & $2.81 \pm 0.2^{\mathrm{b}}$ & $1.12 \pm 0^{\mathrm{b}}$ & $1.69 \pm 0.07^{\mathrm{a}}$ \\
2 & $0.75 \pm 0.03^{\mathrm{a}}$ & $1.74 \pm 0.12^{\mathrm{a}}$ & $1.07 \pm 0.37^{\mathrm{a}}$ & $2.62 \pm 0.08^{\mathrm{b}}$ & $1.08 \pm 0.06^{\mathrm{ab}}$ & $1.84 \pm 0.09^{\mathrm{b}}$ \\
3 & $0.74 \pm 0.03^{\mathrm{a}}$ & $4.08 \pm 0.13^{\mathrm{b}}$ & $1.54 \pm 0.51^{\mathrm{b}}$ & $1.70 \pm 0.04^{\mathrm{a}}$ & $1.07 \pm 0.05^{\mathrm{ab}}$ & $2.94 \pm 0.88^{\mathrm{c}}$ \\
4 & $0.68 \pm 0.02^{\mathrm{a}}$ & $4.22 \pm 0.11^{\mathrm{b}}$ & $1.72 \pm 0.50^{\mathrm{b}}$ & $1.77 \pm 0.51^{\mathrm{a}}$ & $0.95 \pm 0.05^{\mathrm{a}}$ & $2.91 \pm 0.78^{\mathrm{c}}$ \\
\hline
\end{tabular}

Within columns values with different superscripts are significantly different $(\mathrm{P}<0.05)$. a) daily growth ratio $(\%)=[($ weight gain $\times 100) /($ initial weight+ final weight)/2]/time b) voluntary feed intake $(\%)=100 \times$ crude feed intake / initial weight + final weight /2) /time c) feed conversion ration $=$ feed intake $(\mathrm{g}) /$ wet weight gain $(\mathrm{g}) \mathrm{d})$ protein efficiency ratio $=$ wet weight gain $(\mathrm{g}) /$ protein intake. Treatment 1 (Control group) was fed with basal diet and the remaining treatments (2-4) were fed with 50,100 and $200 \mathrm{~g}$ of Echinacea extract in diets respectively. Values are Mean $\pm \mathrm{SE}$

$\mathrm{RBC}, \mathrm{WBC}$, Hct and $\mathrm{Hb}$ were increased in 2, 3, 4 treatments, respectively as Echinacea extract in experimental diets was increased (as shown in Fig. 1). No significant difference was shown in these parameters either between treatment 1 and 2 or between treatment 3 and 4 $(\mathrm{P}>0.05)$. The highest RBC (2.31 \pm 0.18 $\left.\times 10^{6} \mu \mathrm{L}^{-1}\right) \quad$ WBC $\left(20.37 \pm 1.05 \times 10^{3} \mu \mathrm{L}^{-1}\right) \mathrm{Hb}$ $\left(11.48 \pm 1.73 \mathrm{~g} \mathrm{dL}^{-1}\right)$ and Hct ( 36.05 \pm 1.32 $\%)$ were observed in fish fed $200 \mathrm{~g}$ Echinacea extract $\mathrm{kg}^{-1}$. On the other hand, the lowest RBC $\left(2.16 \pm 0.2 \times 10^{6} \mu \mathrm{L}^{-1}\right)$, WBC $(19.9 \pm$ $\left.1.57 \times 10^{3} \mu \mathrm{L}^{-1}\right), \mathrm{Hb}\left(10.40 \pm 0.95 \mathrm{~g} \mathrm{dL}^{-1}\right)$ and Hct ( $29.68 \pm 3.3 \%$ ) were found in fish fed 0.0 $\mathrm{g}$ Echinacea extract $\mathrm{kg}^{-1}$ diet.

\section{Discussion}

As the present study demonstrated, the diets containing Echinacea extract improved the growth performance and nutritional efficiency indices (NEIs) of grey mullet and the highest final weight $(4.22 \mathrm{~g})$, daily growth index $(1.72 \%)$ and the lowest FCR (0.98) is attributed to $200 \mathrm{~g}$ Echinacea extract $\mathrm{kg}^{-1}$ diet fed grey mullet. Whereas no significant difference was shown in all these parameters between fish fed with 100 and 200g Echinacea extract $\mathrm{kg}^{-1}$ diet. A similar result was reported on rainbow trout suggesting that diets containing 0.25 and $0.5 \mathrm{~g}$ Echinacea extract $\mathrm{kg}$ ${ }^{1}$ increased weight gain and specific growth rate significantly compared those fish fed with diets containing $0 \mathrm{~g}$ extract $\mathrm{kg}^{-}$. 

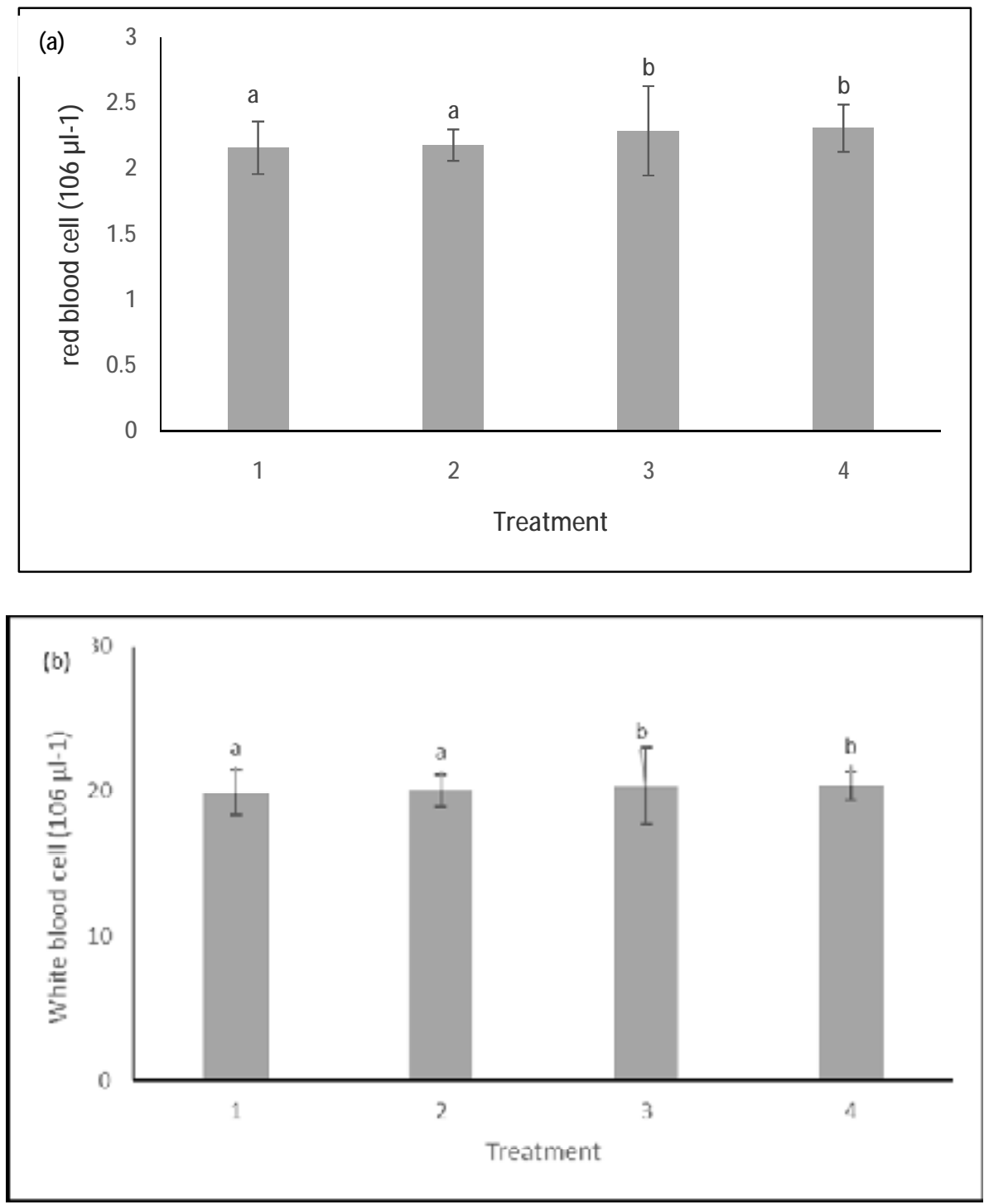

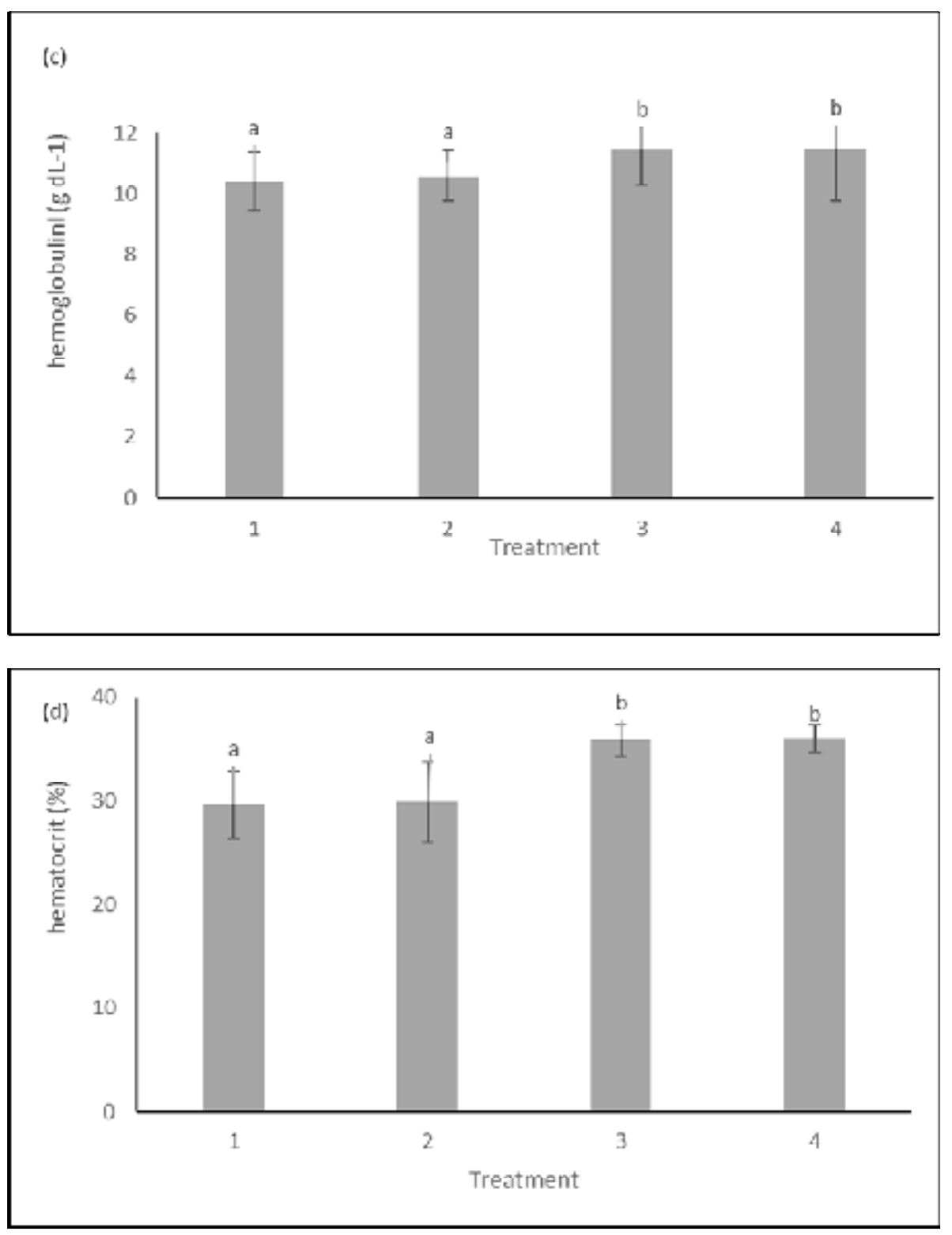

Figure 1. a) Red blood cell (RBC) b), white blood cell (WBC), c) hemoglobin (Hb) and d) hematocrit (Hct) of grey mullet fingerling fed different levels of Echinacea extract. Treatment 1 (Control group) was fed with basal diet and the remaining treatments (2-4) were fed with 50,100 and $200 \mathrm{~g}$ of Echinacea extract in diets respectively. Data represent the mean \pm S.E. Bars assigned with different superscripts are significantly different $(\mathrm{P}>0.05)$.

It was implying that a higher metabolic energy- saving as a trigger for fish growth was observed in those fish fed the diets containing optimum levels of Echinacea extract. Also There was a significant $(\mathrm{P}<0.05)$ decrease in FCR between the control group and the groups fed with diets of 0.25 and $0.5 \mathrm{~g}$ Echinacea extract $\mathrm{kg}^{-1}$ (Oskoii et al. 2012). Also, Kasiri et al. (2011) reported that use of Echinacea extract supplementation improved growth performance of angelfish which agreed with our research. Guz et al. (2011) noted that, in guppy FCR and SGR significantly increased in Echinacea extract- added diet. The mode of action of herb may be through the enhancement functions of the digestive system 
(Przybilla \& Wei 1998 ). In contrast, as a study on with leg shrimp (Litopenaeus vannamei Boone, 1931) pointed out, application of different inclusion levels of Echinacea powder in the diet did not affected growth performance suggesting that the possible factors such as species differences, age and feed composition may be responsible for the discrepancies between published studies (Medina-Beltrán et al. 2012). But, to the best of our knowledge, the present study is the first report on applying E. purpurea in grey mullet diet and its impacts on growth performance and hematological parameter. To specify the optimum dietary E. purpurea extract level based on the biological indices of grey mullet merits further researches.

As hematological analyses proved, RBC, WBC, Hct and $\mathrm{Hb}$ of grey mullet was affected by 100 and $200 \mathrm{~g}$ Echinacea extract $\mathrm{kg}^{-1}$ diet to large extent than 0 and $50 \mathrm{~g}$ Echinacea extract $\mathrm{kg}^{-1}$ diet, whereas either between the diets containing 0 and $50 \mathrm{~g} \mathrm{~kg}^{-1}$ Echinacea extract or between the diets containing 100 and $200 \mathrm{~g} \mathrm{~kg}^{-}$

${ }^{1}$ Echinacea extract. This earlier studies on rainbow trout (Oskoii et al. 2012) and Nile tilapia (Aly et al. 2007 ) are in line with foregoing results, suggesting that the active ingredients in E. purpurea can play main roles on the level of nucleus of many cells in the body. There are contradictory findings as no significant difference was shown in hematological parameters for sows, piglets, and grower/finisher pigs E. purpurea - added diet (Maass et al. 2005). Further research should be done to investigate mechanism of E.purpurea action. Oskoii et al.( 2012) found that in $O$. mykiss $0.5 \mathrm{~g}$ E.purpurea $\mathrm{kg}^{-1}$ added - diet had positive effect on WBC which agreed with our finding. This increase could be related to the efficacy of active ingredients of E. purpurea (caffeic acid. Derivatives, polysaccharides, alkylamides and glycoproteins) in terms of the health status and non-specific immune response

In conclusion, this study reveal that feed supplementation of methanol extract from the brown seaweed E.purpurea has potential of growth-promoting and hematological parameters in M. cephalus. The results from this study also may be useful for grey mullet farming ponds.

\section{Acknowledgment}

We would like to thank the personnel of the Iranian Fisheries Researches Institute, Iran. Special thanks are due to Dr N. Tayari Sadaf laboratory expert, Chabahar, Iran, for her valuable help.

\section{References}

Aly S.M., John G., El-Naggar G. \& Mohamed F. (2007 ) Effect of Echinacea on body gain, survival and some hematological and immunological parameters of Oreochromis niloticus and their response to challenge infection. . Egypt Journal of Aquatic Biological Fish 113, 435-445.

Choi Y.H., Lee B.J. \& Nam T.J. (2015) Effect of dietary inclusion of Pyropia yezoensis extract on biochemical andimmune responses of olive flounder Paralichthys olivaceus Aquaculture 435 .347-353. 
Citarasu T., Sekar R.R., Babu M.M. \& Marian M.P. ( 2002) Developing Artemia enriched herbal diet for producing quality larvae in Penaeus monodon. . Asian Fisheries Science, $15,21-32$.

Goldenfarb P.B., Bowyer F.P., Hall T. \& Brosious E. (1971) Reproductibility in the hematology laboratory: the microhematocrit determination. American Journal of Clinical Pathology 56, 35-39.

Guz L., Sopinska A. \& Oniszczuk T. (2011 ) Effect of Echinacea purpureaon growth and survival of guppy (Poecilia reticulata) challenged with Aeromonas bestiarum. . Aquacultur Nutrient 17, 695-700.

Jayaprakas V. \& Sambhu C. (1996) Growth response of white prawn, Penaeus indicus to dietary L-carnitine Asian Fisheries Society 9, 209-219.

Kasiri M., Farahi A. \& Sudagar M. (2011) Effects of supplemented diets by levamisole and Echinacea purpurea extract on growth and reproductive parameters in angelfish (Pterophyllum scalare). Aquaculture, Aquarium, Conservation \& Legislation International Journal of the Bioflux Society 4, 46-51.

Lee R.G., Foerster J., Jukens J., Paraskevas F., Greer J.P. \& Rodgers G.M. (1998) Wintrobe's-Clinical Hematology, 10rd edn. Lippincott Williams \& Wilkins, New York.
Maass N., Bauer J., Paulicks B.R., Bohmer B.M. \& Roth-Maier D.A. (2005) Efficiency of Echinacea purpurea on growth performance and immune status in pig. . Journal of Animal Physiology and Animal Nutrition 89, 244-252.

Medina-Beltrán V., Luna-González A., FierroCoronado J.A., Campa-Córdova A.I., PerazaGómez V., Carmen Flores-Miranda M. \& Gutiérrez Rivera J.N. (2012) Echinacea purpurea and Uncaria tomentosa reduce the prevalence of WSSV in with leg shrimp (Litopenaeus vannamei) cultured under laboratory conditions. . Aquaculture 358-359 164-169.

Nwabueze A.A. (2012) The Effect of Garlic (Allium sativum) on Growth and Haematological Parameters of Clarias gariepinus (Burchell, 1822). Sustainable Agriculture Research 1, 222-228.

Oskoii S.B., Kohyani A.T., Parseh A., Salati A.P. \& Sadeghi E. ( 2012) Effects of dietary administration of Echinacea purpurea on growth indices and biochemical and hematological indices in rainbow trout (Oncorhynchus mykiss) fingerlings. Fish Physiology and Biochemistry 38(4), 10291034.

Przybilla P. \& Wei J.B. (1998 ) Pflanzliche Futterzusatzstoffe in der Schweinemast. Die Mastleistung natu"rlich verbessern. . DGSMag 40, 52-57. 
Sahu S., Das B.K., Mishra B.K., Pradhan J. \& Sarangi N. (2007) Effect of Allium sativum on the immunity and survival of Labeo rohita infected with Aeromonas hydrophila. Journal of Appled Ichthyology 23, 80-86. .

Shalaby A.M., Khattab Y.M. \& Abdel Rahman A.M. (2006) Effects of garlic (Allium sativum) and chloramphenicol on growth performance, physiological parameters and survival of Nile Tilapia (Oreochromis niloticus). . Journal of Venomous Animimals and Toxins Including Tropical Diseases 12, 172-201.

Shaluei F., Hedayati A., Jahanbakhshi A. \& Baghfalaki M. (2012) Physiological responses of great sturgeon (Huso huso) to different concentrations of 2-phenoxyethanol as an anesthetic. . Fish Physiology and Biochemistry 38, 1627-1634.

Sivaram V., Babu M.M., Citarasu T., Immanuel G., Murugadass S. \& Marian M.P. (2004) Growth and immune response of juvenile greasy groupers (Epinephelus tauvina) fed with herbal antibacterial active principle supplemented diets against Vibrio harveyi infections. . Aquaculture 237, 9-20.

Turan C., Gürlek M., Ergüden D., Yağlioğlu D. \& Öztürka B. (2011) "Systematic status of nine Mullet species (Mugillidae) in the Mediterranean Sea. ." Turkish Journal of Fish Aquatic Science 11, 315-321. 
اثر عصاره متانولى سرخاركل (Echinacea purpurea) بر عملكرد رشد و بارامتر خونى در ماهى كفال خاكسترى (Mugil cephalus)

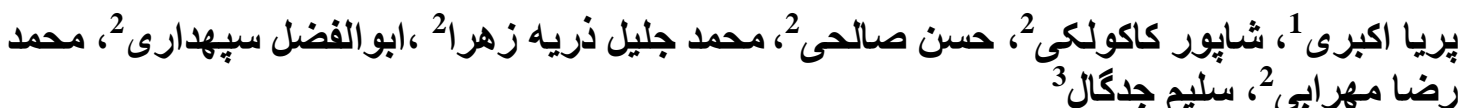

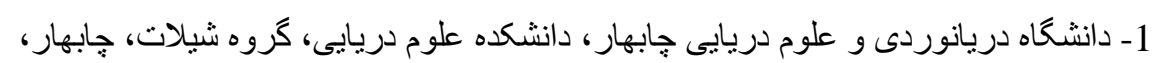

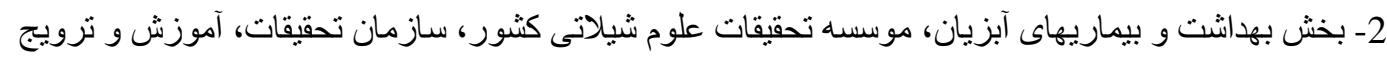
كثاورزى، تهران، ايران 3- مركز تحقيقات آبهاى دور، مو سسه تحققات علوم شيلاتى كثور، سازمان تحقيقات، آموزش و ترويج كشاورزى،

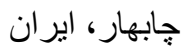

جكيده

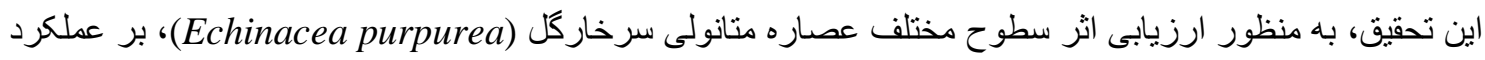

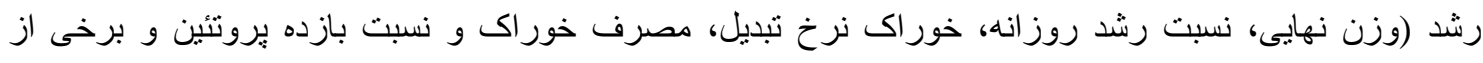

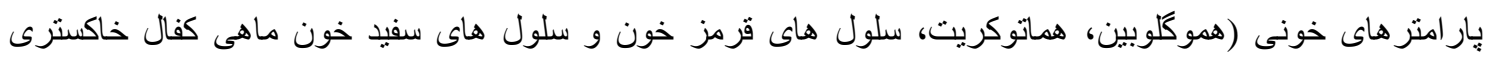

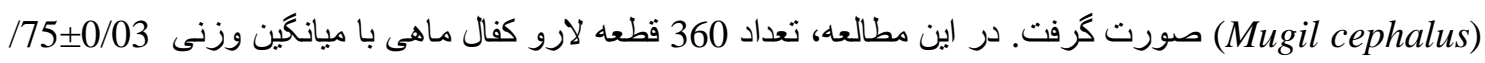

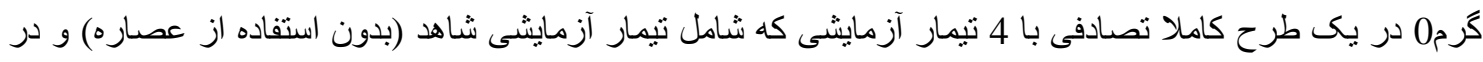

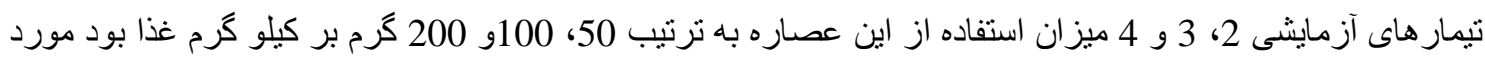

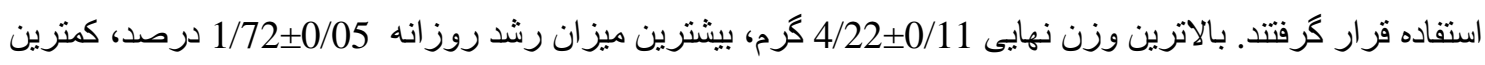

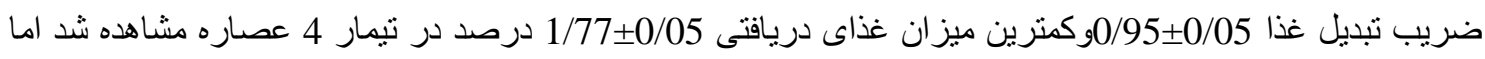

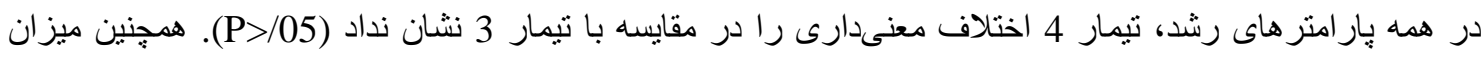

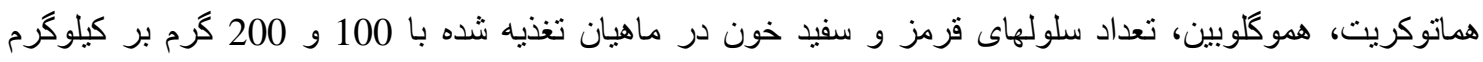

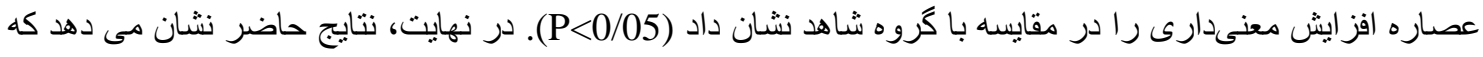

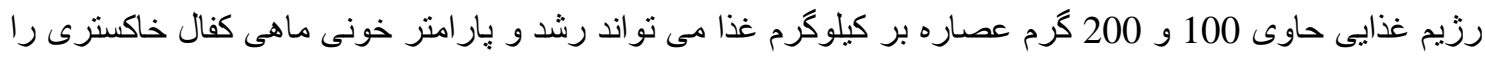
بهبود بخشد.

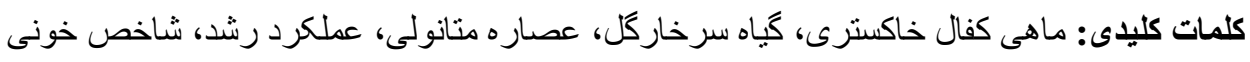

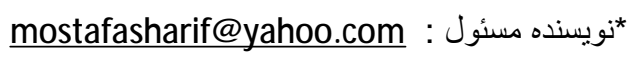

